\title{
Primary Brain Stem Neoplasm
}

National Cancer Institute

\section{Source}

National Cancer Institute. Primary Brain Stem Neoplasm. NCI Thesaurus. Code C4975.

A neoplasm that originates from the brain stem. 